\title{
Copper Sorption and Transport in an Acidic Brown Soil
}

\author{
S. W. Zhou ${ }^{a}$, Z. Z. Song ${ }^{a}$, L. Meng ${ }^{b}$ X. Liu ${ }^{a}$, H. Y. Zhang ${ }^{a}$, and X. L. Bi ${ }^{b}$ * \\ ${ }^{a}$ School of Agriculture, Ludong University, Yantai, 264025 China \\ ${ }^{b}$ Yantai Institute of Coastal Zone Research, Chinese Academy of Sciences, Yantai, 264003 China \\ *e-mail:xlbi@yic.ac.cn \\ Received December 24, 2020; revised May 18, 2021; accepted May 21, 2021
}

\begin{abstract}
The sorption and transport of copper $(\mathrm{Cu})$ in an acidic brown soil were studied using batch and column experiments. The results showed that $\mathrm{Cu}$ adsorption fitted better Langmuir isotherm at low $\mathrm{pH}$ (3.13) whereas Freundlich equation fitted better at high pH (5.87), and affinity ( $K$ and $K_{\mathrm{F}}$ ) increased significantly from 0.00676 to $0.0121 \mathrm{~L} \mathrm{mg}^{-1}$, and from 33.05 to 135.98 , respectively, with pH increase, resulting in a very great increase in adsorption capacity $\left(Q_{\max }\right)$ from 970 to $2272 \mathrm{mg} \mathrm{kg}^{-1}$. Its kinetics was found to be better described by a pseudo-second order model $\left(R^{2}>0.997\right)$, where sorption rate $\left(k_{2}\right.$ and $\left.h\right)$ was as low as 0.0237 and $0.0013 \mathrm{~kg} \mathrm{mg}^{-1} \mathrm{~d}^{-1}$, and 23.89 and $106.12 \mathrm{mg} \mathrm{kg}^{-1} \mathrm{~d}^{-1}$, respectively, at $\mathrm{pH} 3.19$, much lower (10-20 times) than those at $\mathrm{pH}$ 6.92. At $\mathrm{pH} 5.87$, the breakthrough curve of $\mathrm{Cu}$ showed substantial retardation and low peak concentration $\left(C / C_{0}=0.64\right)$; whereas at $\mathrm{pH} 3.17$, full breakthrough $\left(C / C_{0}=1\right)$ was observed, meaning great increase in mobility of $\mathrm{Cu}$. Generally, two different mechanisms governed $\mathrm{Cu}$ sorption and transport: $\mathrm{CuOH}^{+}$was precipitated on clay mineral surface and weaker complexation with DOM at higher $\mathrm{pH}(>5)$; whereas $\mathrm{Cu}^{2+}$ adsorbed to SOM surface and stronger complexation with DOM at lower $\mathrm{pH}(<4.2)$.
\end{abstract}

Keywords: Bordeaux mixture, adsorption capacity of soils

DOI: $10.1134 / \mathrm{S} 106422932110015 \mathrm{X}$

\section{INTRODUCTION}

Copper-based fungicides such as Bordeaux mixture $\left(\mathrm{CuSO}_{4} \cdot 5 \mathrm{H}_{2} \mathrm{O}+\mathrm{Ca}(\mathrm{OH})_{2}\right)$ are used to prevent fungal diseases on a variety of vineyard and orchard soils (apple, grape, pear, cherry, peach, etc.). Their long-term extensive use has led to accumulation and pollution of $\mathrm{Cu}$ in soils [17, 20, 29, 39, 55]. For example, Mirlean et al. [39] showed that $\mathrm{Cu}$ maximum value in Brazil's vineyard soils was much as $3200 \mathrm{mg} \mathrm{kg}^{-1}$, several times higher than $100 \mathrm{mg} \mathrm{kg}^{-1}$, threshold for soil contamination [17]. At high concentrations $\mathrm{Cu}$ is toxic to plants and microorganisms in soils, e.g., reducing the density of root hairs, decreasing photosynthesis, affecting nitrogen metabolism, especially reducing absorption of water and nutrients [9, 50, 57]. In addition, the losses were also expected with $\mathrm{Cu}$ accumulation above the adsorption capacity of soils, causing contamination of surface and subsurface waters.

Numerous studies have demonstrated that $\mathrm{Cu}$ mobility is mainly controlled by sorption to soil organic matter (SOM), where carboxylic and hydroxylic (or amine) groups form very stable five- to sixmembered ring chelates with $\mathrm{Cu}^{2+}[11,18,21,27,35]$. $\mathrm{Cu}$ can also adsorb to $\mathrm{Fe}-$, $\mathrm{Mn}$ - or $\mathrm{Al}$-(hydro)oxides, and clay minerals, forming inner-sphere complexes and/or surface precipitates [7, 8, 14, 46]. Such strong sorption made it one of the least mobile metals in soils. However, Sun et al. [50] showed that $\mathrm{Cu}$ has potential to leach from surface horizon into a lower horizon in extreme sandy soils with little SOM $(<0.5 \%)$.

Shandong Peninsula of China is an important fruit-producing area, where brown soil is the dominant soil type, and strong acidification occurred after 40 -year intensive cultivation, resulting in a $1.5 \mathrm{pH}$ decrease from 6.8 to 5.3 [54]. More importantly, its SOM decreased linearly with soil acidification and was $2.3 \%$ for $\mathrm{pH} 6$ and $0.74 \%$ for $\mathrm{pH} 4$ [54]. Our investigation in Hunan, Jiangxi and Shandong also showed a high positive linear correlation between SOM and soil $\mathrm{pH}$ (data not shown). The low SOM content driven by soil acidification probably weakened $\mathrm{Cu}$ sorption and thus promoted its mobility. Some researches evidenced that dissolved organic matter (DOM) governed the mobilization of $\mathrm{Cu}$ due to $\mathrm{Cu}$-DOM complexation [26, 58], and even Mehlhorn et al. [36] suggested the DOM : SOM ratios. The solubility of DOM is $\mathrm{pH}$-dependent and significant increases in DOM have been observed when $\mathrm{pH}$ is raised [13, 40]. Obviously, there is a confliction in the descriptions for $\mathrm{Cu}$ mobility at lower $\mathrm{pH}$ where whether it increased due to a decrease in sorption capacity (releasing freer $\mathrm{Cu}$ (II) ions) or whether it decreased due to a decrease in DOM concentration (producing less DOM-Cu (II) complexes). Temminghoff et al. [52] showed that although DOM-Cu at low pH (3.9) was only about $1 / 3$ of that at high $\mathrm{pH}(6.6)$, extractable $\mathrm{Cu}$ concentration 
for the former was about 5 times larger than that for the latter, implying the increase in $\mathrm{Cu}$ mobility at low $\mathrm{pH}$. Our previous study [60] evidenced that $\mathrm{Cu}$ sorption on soils is governed by $\mathrm{pH}$-regulated surface adsorption followed by diffusion into the micropores of SOM and/or clay minerals, where surface precipitation or polymerization of $\mathrm{CuOH}^{+}$dominated at higher $\mathrm{pH}$ whereas at lower $\mathrm{pH}$ the micropore diffusion of $\mathrm{Cu}^{2+}$ made a considerable contribution to aging (decreasing its mobility). Therefore, the complex changes that occurred during soil acidification due to the different dominant sorption species and sorption mechanisms have led to great changes in $\mathrm{Cu}$ mobility that are difficult to predict.

In any events, it is crucial to understand $\mathrm{Cu}$ behavior and fate in acidified soils. In this study, the kinetics of sorption and transport of $\mathrm{Cu}$ in an acidic Cambisols under different $\mathrm{pHs}$ were investigated. The objectives were: (1) to quantify the influence of $\mathrm{pH}$ on the sorption rate and transport of $\mathrm{Cu}$; and (2) to determine the fate and behavior of $\mathrm{Cu}$ in response to soil acidification.

\section{OBJECTS AND METHODS}

Soil sample. Surface soil $(0-20 \mathrm{~cm}$ depth) under a pine forest at the foot of Phoenix Hill, Yantai, Shandong, China $\left(121.44^{\circ} \mathrm{E}, 37.47^{\circ} \mathrm{N}\right)$, was collected in October 2012, air-dried, ground and passed through a $2 \mathrm{~mm}$-sieve for batch and column experiments. Following the methods described by Lu [33], the soil basic properties were determined as follows: $\mathrm{pH} 5.87$, organic matter (SOM) $2.84 \%$, total $\mathrm{Cu} 14.0 \mathrm{mg} \mathrm{kg}^{-1}$, and sand $(2.00-0.05 \mathrm{~mm}) 67.0 \%$, silt $(0.05-0.002 \mathrm{~mm})$ $31.1 \%$ and clay $(<0.0002 \mathrm{~mm}) 1.9 \%$. Briefly, the soil $\mathrm{pH}$ was determined using a $\mathrm{pH}$ meter (PHS-3C, Shanghai INESA Instruments Co., Ltd., Shanghai, China) in a soil/water ratio of $1: 2.5(\mathrm{~V}: \mathrm{V})$; SOM was measured by potassium dichromate oxidation titration; Total $\mathrm{Cu}$ content was determined by atomic absorption spectrophotometer (AAS) (ZEEnit 700, Analytik Jena AG, Germany) after triacid digestion $\left(\mathrm{HNO}_{3}-\mathrm{HClO}_{4}-\mathrm{HF}\right)$. Soil sand, silt and clay were measured using a laser particle analyzer (Malvern Mastersizer 2000F, Malvern Instruments Ltd., UK). This sandy acidic soil was classified as Cambisols (WRB 2014) [24].

Equilibrium batch experiments. $\mathrm{H}^{+}$would be released during $\mathrm{Cu}$ sorption, but the effect may be partly offset in some concentration of electrolyte in particular nitrate for constant charge soils [42, 61]. So, $0.005 \mathrm{M} \mathrm{Ca}\left(\mathrm{NO}_{3}\right)_{2}$ was used as supporting electrolyte in this study to keep ionic strength constant and maintain a more consistent matrix during sorption and transport of $\mathrm{Cu}$.

Equilibrium batch experiments were conducted to obtain adsorption isotherms and adsorption edges of $\mathrm{Cu}$ in the soil $[23,49]$. For adsorption isotherms, the experiments were initiated by mixing $3.0 \mathrm{~g}$ soil with $10 \mathrm{~mL}$ background solution $\left[0.005 \mathrm{M} \mathrm{Ca}\left(\mathrm{NO}_{3}\right)_{2}\right]$ in
$50 \mathrm{~mL}$ centrifuge tubes. The $\mathrm{pH}$ of mixture was measured using $\mathrm{pH}$-meter and adjusted repeatedly with $0.5 \mathrm{M} \mathrm{HNO}_{3} / \mathrm{Ca}(\mathrm{OH})_{2}$ to initial $\mathrm{pH} 3$ or 6 . Then $0.005 \mathrm{M} \mathrm{Ca}\left(\mathrm{NO}_{3}\right)_{2}$ solution was added until the total volume of supernatant solutions reached $20 \mathrm{~mL}$. Finally, $10 \mathrm{~mL} \mathrm{Cu}$ solutions [prepared in $0.005 \mathrm{M} \mathrm{Ca}\left(\mathrm{NO}_{3}\right)_{2}$ ] with wide range of initial concentrations $(0.15 \sim 30 \mathrm{mM})$ were added and the centrifuge tubes were capped. For adsorption edges, the $\mathrm{pH}$ of mixture was adjusted to initial values of $3,4,5,6$, and 7 , respectively, and followed by adding $10 \mathrm{~mL} 1.0 \mathrm{mM} \mathrm{Cu}\left(\mathrm{NO}_{3}\right)_{2}$ in $0.005 \mathrm{M}$ $\mathrm{Ca}\left(\mathrm{NO}_{3}\right)_{2}$ solution (soil/water $=1 / 10$ ).

All centrifugal tubes were continuously shaken in a constant temperature water bath shaker $(\mathrm{HZS}-\mathrm{H}$, Harbin Donglian Eelectronic and Technolgy Development Co., Ltd., Heilongjiang, China) at $25^{\circ} \mathrm{C}$ for $24 \mathrm{~h}$ followed by centrifuging at $4000 \mathrm{rpm} \mathrm{min}{ }^{-1}$ for $15 \mathrm{~min}$. The $\mathrm{Cu}$ concentration in supernatant solutions was analyzed using AAS. All treatments were conducted in triplicates.

Kinetic batch experiments. The time-dependent sorption of $\mathrm{Cu}$ in the soil was determined using kinetic batch experiments under various $\mathrm{pHs}$. According to the same procedure mentioned above, the mixture ( $3 \mathrm{~g}$ soil $+30 \mathrm{~mL}$ solution) was adjusted to initial $\mathrm{pH}$ of 3,5 , and 7 , respectively. The initial concentration of $\mathrm{Cu}$ [as $\mathrm{Cu}\left(\mathrm{NO}_{3}\right)_{2}$ prepared in $0.005 \mathrm{M} \mathrm{Ca}\left(\mathrm{NO}_{3}\right)_{2}$ ] were $0.15 \mathrm{mM}$ and $1.5 \mathrm{mM}$, respectively. The centrifuge tubes were capped and incubated in a constanttemperature incubator (BPX-272, Boxun Medical Biological Instrument Corp., Shanghai, China) at $25^{\circ} \mathrm{C}$ for $1,5,10,28$, and 90 days, respectively. After the incubation, the supernatant solutions were centrifuged at $4000 \mathrm{rpm} \mathrm{min}^{-1}$ for $15 \mathrm{~min}$ and $\mathrm{Cu}$ concentrations were measured using AAS. All treatments were conducted in triplicates.

Column experiments. Miscible displacement column experiments as described by Elbana and Selim [15] were performed in an air-conditioner laboratory for maintaining constant temperature $\left(25^{\circ} \mathrm{C}\right)$ during whole experiment process. Two acrylic columns (A and B) (10-cm in length and of $2.2 \mathrm{~cm}$ i.d.) were uniformly packed with air-dry soil, and the basic characteristics were given in Table 1. To ensure water saturation, upward flow in the soil columns was maintained. Constant flux was controlled by a peristaltic pump (BT 102S, Baoding Longer Precision Pump Co., Hebei, China). Effluents from columns were collected using an automatic fraction collector (CBS-A, Shanghai Huxi Analysis Instrument Factory Co., China) at regular time interval and analyzed by AAS.

Column A was initially saturated with a background solution of $0.005 \mathrm{M} \mathrm{Ca}\left(\mathrm{NO}_{3}\right)_{2}$ ( $\mathrm{pH}$ 5.87). Following saturation, approximately 145 pore volumes of $10 \mathrm{mg} \mathrm{L}^{-1} \mathrm{Cu}$ [in the form of $\mathrm{Cu}\left(\mathrm{NO}_{3}\right)_{2}$ in $0.005 \mathrm{M}$ $\mathrm{Ca}\left(\mathrm{NO}_{3}\right)_{2}$ ] with $\mathrm{pH}$ of 5.87 was introduced into the column. After that, the column was leached with 

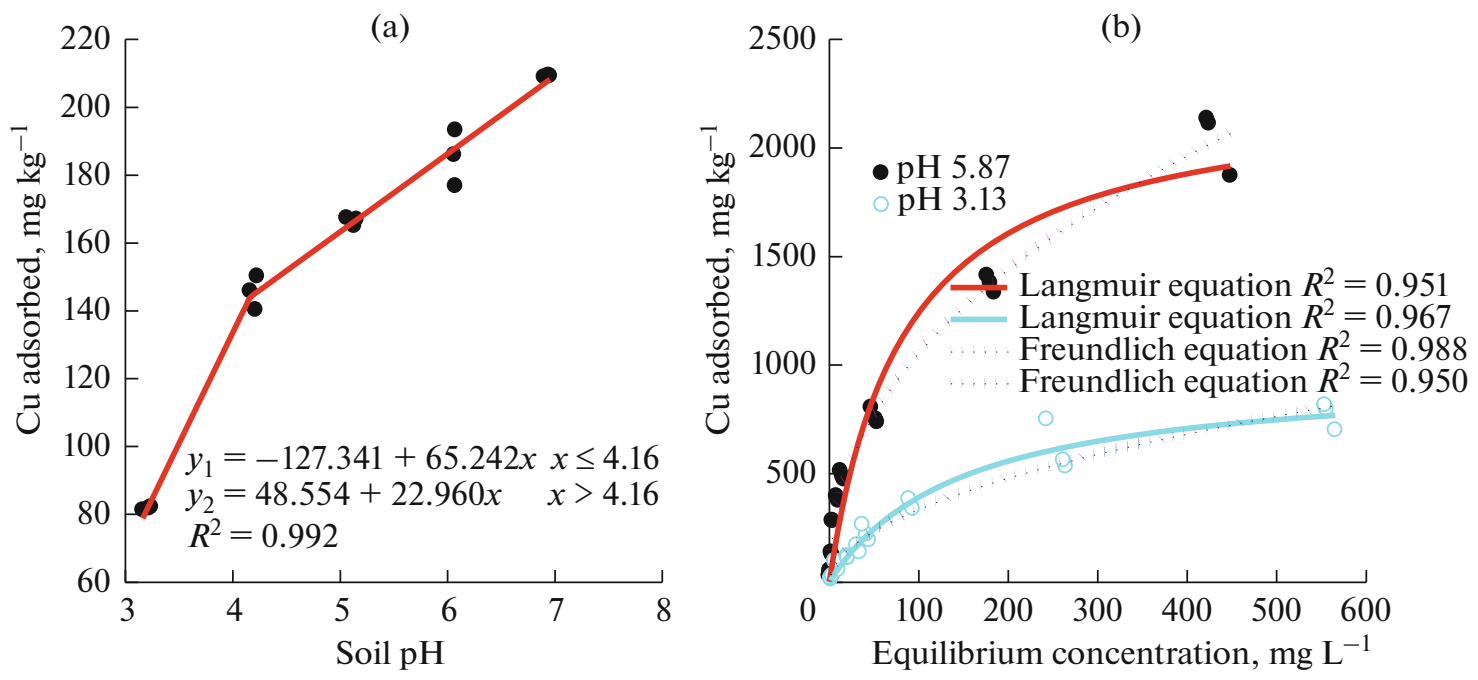

Fig. 1. (a) Effect of $\mathrm{pH}$ on $\mathrm{Cu}$ adsorption $\left(C_{0}=0.33 \mathrm{mM}\right)$; (b) $\mathrm{Cu}$ adsorption isotherms at $\mathrm{pH} 3.13$ and 5.87 .

about 102 pore volumes of $0.005 \mathrm{M} \mathrm{Ca}\left(\mathrm{NO}_{3}\right)_{2}$ with $\mathrm{pH}$ of 5.87. To measure the effect of soil acidification on copper release, column A was further leached with $0.005 \mathrm{M} \mathrm{Ca}\left(\mathrm{NO}_{3}\right)_{2}$ solution adjusted to $\mathrm{pH} 3.17$.

Similarly, column B was initially saturated with $0.005 \mathrm{M} \mathrm{Ca}\left(\mathrm{NO}_{3}\right)_{2}$ adjusted to $\mathrm{pH} 3.17$ followed by approximately 80 pore volumes of $10 \mathrm{mg} \mathrm{L}^{-1} \mathrm{Cu}$ in $0.005 \mathrm{M} \mathrm{Ca}\left(\mathrm{NO}_{3}\right)_{2}(\mathrm{pH} 3.17)$, and then leached with $0.005 \mathrm{M} \mathrm{Ca}\left(\mathrm{NO}_{3}\right)_{2}(\mathrm{pH} 3.17)$.

\section{RESULTS AND DISCUSSION}

pH-dependent adsorption isotherms of $\mathrm{Cu}$. $\mathrm{Cu}$ adsorption increased markedly from 81.5 to $209.2 \mathrm{mg} \mathrm{kg}^{-1}$ (38.5 to $98.8 \%$ of added $\mathrm{Cu}$ ) with increase in $\mathrm{pH}$ from 3.2 to 6.9 , yielding two linear segments with different slopes (Fig. 1a). One was 65.2 at $\mathrm{pH}<4.2$, and the other was 23.0 at $\mathrm{pH}>4.2$, which means that two adsorption mechanisms were possible with increase of soil $\mathrm{pH}$ : monolayer and multilayer adsorption at low coverages at low $\mathrm{pH}$, and surface precipitation or surface polymerization at high coverages at high $\mathrm{pH}$. Furthermore, $\mathrm{Cu}$ adsorption isotherms at low (3.13) and high (5.87) $\mathrm{pH}$ were shown in Fig. $1 \mathrm{~b}$ and Table 2. Langmuir and Freundlich adsorption models displayed good fits $\left(R^{2}=0.950 \sim 0.988\right)$, where affinity parameters related to the bonding energy ( $K$ and $K_{\mathrm{F}}$ ) increased significantly from 0.00676 to $0.0121 \mathrm{~L} \mathrm{mg}^{-1}$, and from
33.05 to 135.98 , respectively, with $\mathrm{pH}$ increase from 3.13 to 5.87 , and thus causing a very great increase in adsorption capacity $\left(Q_{\max }\right)$ from 970 to $2272 \mathrm{mg} \mathrm{kg}^{-1}$. Moreover, the decrease in Freundlich parameter $b$ representing dimensionless heterogeneity [19] with $\mathrm{pH}$, suggested that at lower $\mathrm{pH}(<4.2) \mathrm{Cu}$ adsorption was possibly a homogeneous adsorption, whereas at higher $\mathrm{pH}(>4.2)$ nucleation and surface precipitation with non-uniform distribution of adsorption affinities over the heterogeneous surface might occur $[3,5,19,51]$.

In addition, Langmuir isotherm seems good for $\mathrm{Cu}$ adsorption at lower $\mathrm{pH}$ while Freundlich is better for its adsorption at higher $\mathrm{pH}$, which also suggested that two adsorption mechanisms are at work: adsorption on homogeneous surfaces and followed by nucleation on heterogeneous surfaces. Lodygin [32] also showed possible existence of two fixation mechanisms of $\mathrm{Cu}$ ions on the surface of humic acid. In short, $\mathrm{Cu}$ adsorption on Cambisols was highly $\mathrm{pH}$-dependent, resulting in lower adsorption at lower $\mathrm{pH}$ whereas higher nucleation/precipitation at higher $\mathrm{pH}$. Generally, surface negative charge increases with increasing $\mathrm{pH}$, causing marked increase in metal cation adsorption. More importantly, monovalent metal cation $\left(\mathrm{MOH}^{+}\right)$, which adsorbs more easily on soil surfaces than bivalent cation $\left(\mathrm{M}^{2+}\right)$, also increases with increase in $\mathrm{pH}$, resulting in surface nucleation/precipitation of hydroxides of transition metals [6]. Surface clusters of Cu hydrox-

Table 1. Conditions of soil column displacement experiments

\begin{tabular}{l|c|c|c|c|c}
\hline Column & $\mathrm{pH}$ & $\begin{array}{c}\text { Bulk density, } \\
\mathrm{g} \mathrm{cm}^{-3}\end{array}$ & $\begin{array}{c}\text { Saturated water } \\
\text { content, } \mathrm{cm}^{3} \mathrm{~cm}^{-3}\end{array}$ & $\begin{array}{c}\text { Darcy velocity, } \\
\mathrm{cm} \mathrm{min}\end{array}$ & $\begin{array}{c}\text { Average pore-water } \\
\text { velocity, } \mathrm{cm} \mathrm{min}^{-1}\end{array}$ \\
\hline $\mathrm{A}$ & 5.87 & 0.99 & 0.627 & 0.0295 & 0.0470 \\
$\mathrm{~B}$ & 3.17 & 1.03 & 0.611 & 0.0460 & 0.0753 \\
\hline
\end{tabular}


ZHOU et al.
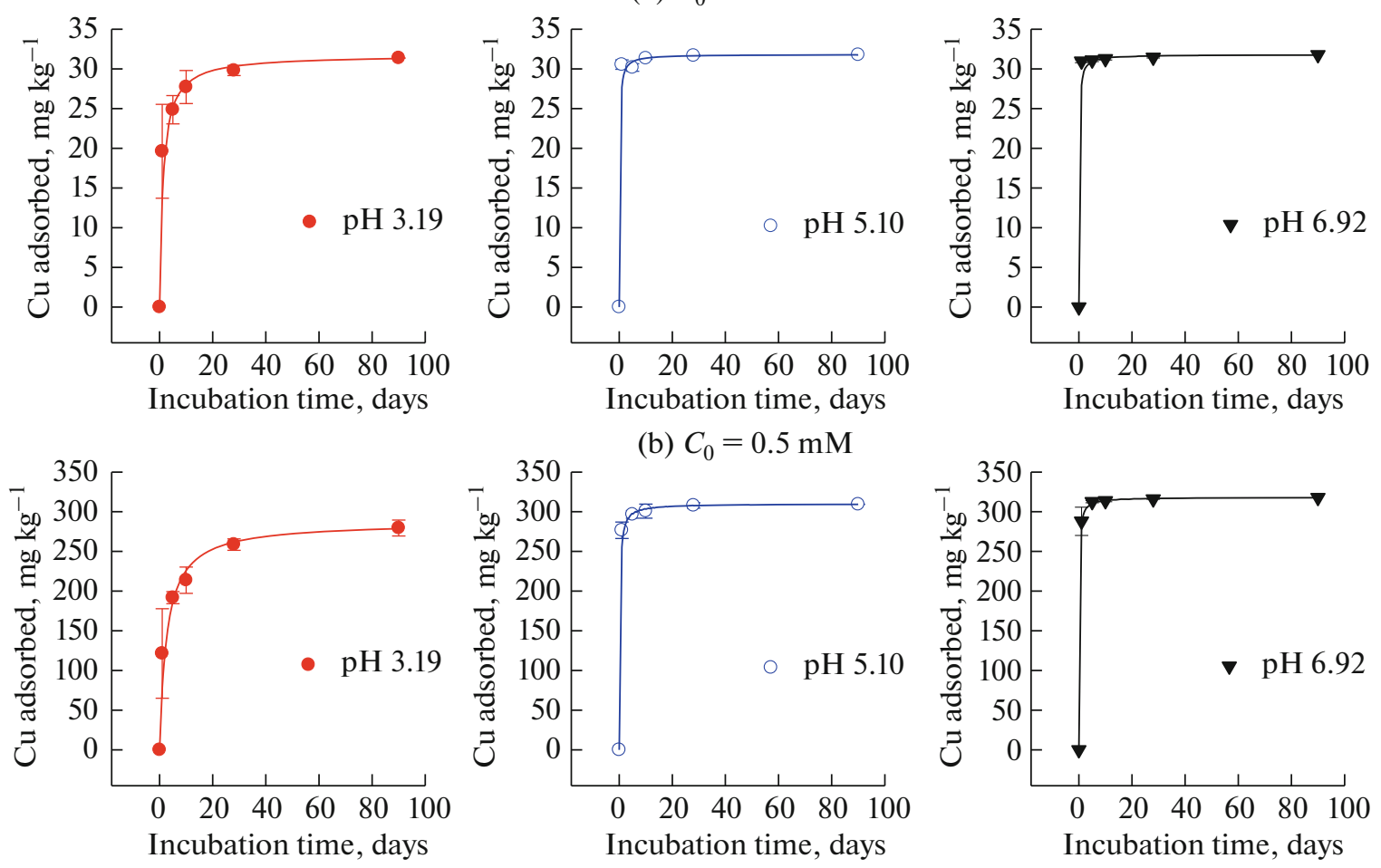

Fig. 2. Effect of $\mathrm{pH}$ on $\mathrm{Cu}$ slow reaction (irreversible process) onto Cambisols ((a) $C_{0}=0.05 \mathrm{mM}$; (b) $C_{0}=0.5 \mathrm{mM}$ ).

ide and/or precipitates of $\mathrm{Cu}(\mathrm{OH})_{2}$ can form at high $\mathrm{pH}$ (e.g., 7.5 and 5.6, respectively, for hydrous oxides of $\mathrm{Fe}$ and $\mathrm{Al}$ ), which has been confirmed by spectra data $[1,10,28]$.

Slow kinetics of $\mathrm{Cu}$ added to Cambisols. $\mathrm{Cu}$ sorption showed a pronounced aging effect, especially under lower $\mathrm{pH}$ and higher initial concentration, where $\mathrm{Cu}$ mobility and bioavailability declines continuously and slowly with time, lasting for several months or years (Fig. 2) [2, 31, 34, 45, 60]. For example, Arias-Estevez et al. [2] demonstrated that 500 days of incubation in an acidic soil were still inadequate for the aging of added $\mathrm{Cu}$ more than $500 \mathrm{mg} \mathrm{kg}^{-1}$.

Various kinetic models such as Lagergren pseudofirst order, pseudo-second order, Elvoich, and intraparticle diffusion equation have been widely applied to describing ion reaction at the particle/solution interface [16, 47, 48]. Among them Lagregren pseudo-first order rate equation is:

$$
\ln \left(q_{e}-q_{t}\right)=\ln q_{e}-k_{1} t
$$

where $q_{e}$ and $q_{t}$ are the amount adsorbed $\left(\mathrm{mg} \mathrm{kg}^{-1}\right)$ at equilibrium and at any time $t(\mathrm{~d}) ; k_{1}$ is the rate constant of Lagergren pseudo-first order model $\left(\mathrm{d}^{-1}\right)$.

Pseudo-second order equation is expressed as:

$$
\frac{t}{q_{t}}=\frac{1}{k_{2} q_{e}^{2}}+\frac{1}{q_{e}} t
$$

where $k_{2}$ is the rate constant of pseudo-second order model $\left(\mathrm{kg} \mathrm{mg}^{-1} \mathrm{~d}^{-1}\right)$. The initial adsorption rate $\left(\mathrm{mg} \mathrm{kg}^{-1} \mathrm{~d}^{-1}\right), h$, of the second order process as $t \rightarrow 0$ is defined as:

$$
h=k_{2} q_{e}^{2},
$$

Elovich equation is generally simplified as follows:

$$
q_{t}=\left(\frac{1}{\beta}\right) \ln (\alpha \beta)+\left(\frac{1}{\beta}\right) \ln t,
$$

Table 2. Estimated parameters using Langmuir and Freundlich equations for $\mathrm{Cu}$ adsorption at different $\mathrm{pHs}$

\begin{tabular}{c|c|c|c|c|c|c}
\hline \multirow{2}{*}{$\mathrm{pH}$} & \multicolumn{3}{|c|}{ Langmuir equation } & \multicolumn{3}{c}{ Freundlich equation } \\
\cline { 2 - 7 } & $Q_{\max }, \mathrm{mg} \mathrm{kg}^{-1}$ & $K, \mathrm{~L} \mathrm{mg}^{-1}$ & $R^{2}$ & $K_{\mathrm{F}}$ & $b$ & $R^{2}$ \\
\hline 5.87 & 2271.93 & 0.0121 & 0.951 & 135.98 & 0.446 & 0.988 \\
3.13 & 969.89 & 0.00676 & 0.967 & 33.05 & 0.506 & 0.950 \\
\hline
\end{tabular}


Table 3. Kinetic parameters for the slow reaction of $\mathrm{Cu}$ at different $\mathrm{pHs}$

\begin{tabular}{|c|c|c|c|c|c|c|c|c|c|c|c|c|c|}
\hline \multirow{2}{*}{$\mathrm{pH}$} & \multicolumn{3}{|c|}{$\begin{array}{l}\text { Lagergren pseudo } \\
\text { first-order }\end{array}$} & \multicolumn{4}{|c|}{ Pseudo second-order } & \multicolumn{3}{|c|}{ Elovich } & \multicolumn{3}{|c|}{$\begin{array}{l}\text { Intraparticle } \\
\text { diffusion }\end{array}$} \\
\hline & $q_{e}$ & $k_{1}$ & $R^{2}$ & $q_{e}$ & $k_{2}$ & $h$ & $R^{2}$ & $\alpha$ & $\beta$ & $R^{2}$ & $q_{e}$ & $D / r^{2}$ & $R^{2}$ \\
\hline \multicolumn{14}{|c|}{$C_{0}=0.05 \mathrm{mM}$} \\
\hline 3.19 & 28.50 & 1.147 & 0.966 & 31.75 & 0.0237 & 23.89 & 0.9997 & $5.77 \times 10^{3}$ & 0.376 & 0.961 & 28.60 & 0.119 & 0.9768 \\
\hline 5.10 & 31.25 & 3.798 & 0.998 & 31.85 & 0.210 & 213.03 & 1 & $1.15 \times 10^{38}$ & 2.927 & 0.6807 & 38.99 & 0.159 & 0.9588 \\
\hline 6.92 & 31.41 & 4.295 & 0.9997 & 31.85 & 0.224 & 227.23 & 1 & $4.89 \times 10^{74}$ & 5.621 & 0.9506 & 39.56 & 0.159 & 0.9597 \\
\hline \multicolumn{14}{|c|}{$C_{0}=0.5 \mathrm{mM}$} \\
\hline 3.19 & 244.68 & 0.497 & 0.9254 & 285.71 & 0.0013 & 106.12 & 0.9978 & $1.29 \times 10^{3}$ & $2.78 \times 10^{-2} \mid$ & 0.9799 & 211.08 & $8.10 \times 10^{-2}$ & 0.9903 \\
\hline 5.10 & 303.68 & 2.265 & 0.9985 & 312.50 & 0.0146 & 1425.78 & 1 & $4.13 \times 10^{15}$ & 0.122 & 0.8711 & 359.28 & 0.148 & 0.9655 \\
\hline 6.92 & 315.04 & 2.456 & 0.9998 & 322.58 & 0.0240 & 2497.39 & 1 & $3.30 \times 10^{21}$ & 0.162 & 0.743 & 378.49 & 0.150 & 0.9652 \\
\hline
\end{tabular}

Unit: $q_{e}\left(\mathrm{mg} \mathrm{kg}^{-1}\right), k_{1}\left(\mathrm{~d}^{-1}\right), k_{2}\left(\mathrm{~kg} \mathrm{mg}^{-1} \mathrm{~d}^{-1}\right), h\left(\mathrm{mg} \mathrm{kg}^{-1} \mathrm{~d}^{-1}\right), \alpha\left(\mathrm{mg} \mathrm{kg}^{-1} \mathrm{~d}^{-1}\right), \beta\left(\mathrm{kg} \mathrm{mg}^{-1}\right), D / r^{2}\left(\mathrm{~d}^{-1}\right)$.

where $\alpha$ is the initial adsorption rate $\left(\mathrm{mg} \mathrm{kg}^{-1} \mathrm{~d}^{-1}\right)$ and $\beta$ is the desorption constant $\left(\mathrm{kg} \mathrm{mg}^{-1}\right)$.

Intraparticle diffusion equation can be written as follows:

$$
\frac{q_{t}}{t q_{e}}=\frac{4 \sqrt{\frac{D}{\pi r^{2}}}}{\sqrt{t}}-\frac{D}{r^{2}},
$$

where $D$ is the diffusion coefficient $\left(\mathrm{cm} \mathrm{d}^{-1}\right), r$ is the radius of the spherical particle $(\mathrm{cm})$, and the term $D / r^{2}$ expresses the apparent diffusion coefficient $\left(\mathrm{d}^{-1}\right)$.

The pseudo-second order kinetic model was best for the description of the slow reaction of $\mathrm{Cu}$ onto Cambisols $\left(R^{2}>0.997\right)$, and the reaction rate coefficients all increased markedly with increase in soil $\mathrm{pH}$ or decrease in initial $\mathrm{Cu}$ concentration (Table 3). For example, the values of $k_{2}$ at $\mathrm{pH} 3.19$ were 0.0237 and $0.0013 \mathrm{~kg} \mathrm{mg}^{-1} \mathrm{~d}^{-1}$, respectively, for $C_{0}=0.05$ and $0.5 \mathrm{mM}$; while the values of $h$ were 23.89 and $106.12 \mathrm{mg} \mathrm{kg}^{-1} \mathrm{~d}^{-1}$, respectively, which was much lower (about 10 and 20 times) than those at pH 6.92. Obviously, during soil acidification the longer time was required for the sorption of more $\mathrm{Cu}$ ions; the higher was $C_{0}$ (or the lower was $\mathrm{pH}$ ), the longer time was required to reach an equilibrium. Therefore, when more dissolved $\mathrm{Cu}$ (e.g., Bordeaux mixture) was added to a strong acidified soil, higher healthy and environmental risk would occur under strong precipitation or flooding irrigation due to insufficient sorption.

Pseudo-second order equation has been widely applied to describing kinetics of adsorption of metal ions on soils [12, 22, 43, 44, 47], implying that the rate-limiting step may be chemical sorption involving force through sharing or exchange of electrons between $\mathrm{Cu}$ ions and the hydroxyl groups of soil surface $[47,56]$.

Aging moved metals from soil surfaces to deeper in the solid phase through micropore diffusion, surface nucleation/precipitation and occlusion by mineral/SOM, where micropore diffusion was assumed as the rate-limiting step for overall sorption $[34,53,60]$. If initial rapid adsorption (within $24 \mathrm{~h}$ ) was considered to be from surface nucleation/precipitation, the contribution of micropore diffusion to overall sorption could be assessed by the difference between total sorption amount and adsorption amount within $24 \mathrm{~h}$ (Table 4). It could be observed that at strong acidic (pH 3.19) condition, about $40-60 \%$ of sorption of $\mathrm{Cu}$ was governed by the relatively slow micropore diffusion process; while this contribution ratio was minimal at higher $\mathrm{pH}(6.92)$, being less than $10 \%$. These results supported again that $\mathrm{Cu}$ sorption on Cambisols with $\mathrm{pH}$ was mainly controlled by two mechanisms: surface adsorption and micropore diffusion at low $\mathrm{pH}$; surface nucleation and precipitation at high $\mathrm{pH}$.

pH-dependent $\mathrm{Cu}$ transport. Transport of $\mathrm{Cu}$ in soil columns were illustrated by breakthrough curves (BTCs) in Fig. 3. Significant retardation or delayed movement of $\mathrm{Cu}$ was observed in soil column A with $\mathrm{pH}$ 5.87. The BTC was also characterized by low peak concentration $\left(C / C_{0}=0.64\right)$. The result demonstrated strong retention of $\mathrm{Cu}$ in Cambisols under weak acidic condition. In contrast, the BTC of soil column B with $\mathrm{pH} 3.17$ showed little $\mathrm{Cu}$ retardation and full breakthrough with peak concentration $C / C_{0}=1$ was observed. In addition, changing $\mathrm{pH}$ of introduced $\mathrm{Ca}\left(\mathrm{NO}_{3}\right)_{2}$ solution from $\mathrm{pH} 5.87$ to $\mathrm{pH} 3.17$ resulted in the release of large amount of residual $\mathrm{Cu}$ in column $\mathrm{A}$. These results clearly evidenced that $\mathrm{Cu}$ transport in soils was enhanced deep under strong acidic environment.

Mirlean et al. [39] found that soil acidity favored deeper penetration of $\mathrm{Cu}$ along the soil profile, and in Arenosol vineyard soils (about $\mathrm{pH}$ 4) pesticidederived $\mathrm{Cu}$ reached the groundwater horizon at the depth of about $1.0 \mathrm{~m}$. Strong retention of $\mathrm{Cu}$ by soil components such as $\mathrm{Fe}$-, $\mathrm{Al}-$, and $\mathrm{Mn}$-oxides, organic matter and clay minerals made it less mobile $[7,8,11$, 

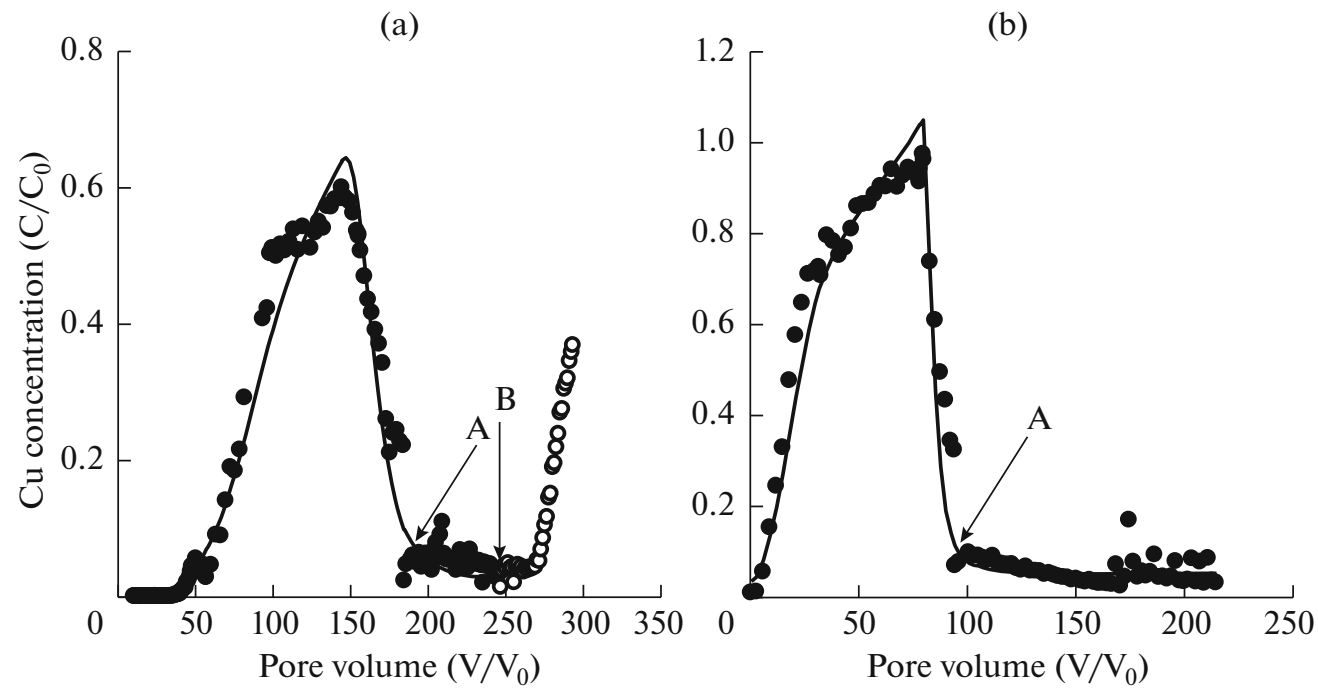

Fig. 3. Breakthrough curves of $\mathrm{Cu}$ from Cambisols at (a) $\mathrm{pH} 5.87$ and (b) $\mathrm{pH}$ 3.17. The arrow A indicated that the flow interruption occurred when the time lasted for 44 days; and arrow $\mathrm{B}$ is that the $\mathrm{pH}$ of introduced $\mathrm{Ca}\left(\mathrm{NO}_{3}\right)_{2}$ solution was adjusted from $\mathrm{pH} 5.87$ to $\mathrm{pH} 3.17$.

$27,35,46]$; but the retention was highly $\mathrm{pH}$-dependent. $\mathrm{Cu}$ adsorption capacity $\left(Q_{\max }\right)$, affinity $(K$ and $\left.K_{\mathrm{F}}\right)$, and slow kinetic rate $\left(k_{2}\right.$ and $\left.h\right)$ all decreased markedly under acidified condition, as shown above, resulted in higher mobility.

In addition, Fig. 3 showed that little $\mathrm{Cu}$ was leached by $\mathrm{Ca}\left(\mathrm{NO}_{3}\right)_{2}$ solution after 44 days of incubation, suggesting that aging (slowly irreversible reaction) strongly affected $\mathrm{Cu}$ transport in soils by reducing the amount of available $\mathrm{Cu}$ [45]. So, the irreversible kinetic process must be considered for modeling the reaction and transport of $\mathrm{Cu}$ in soils, especially under strong acidic condition as $\mathrm{pH}<4$. Elbana and Selim [15] have demonstrated that improved predictions could be obtained when nonlinear kinetic irreversible reaction was incorporated into the multi-reaction and transport model (MRTM). However, $\mathrm{pH}$ was not considered in the current version of MRTM, which made it unsuitable for simulating the reaction and transport of metals under changing environmental conditions. Geochemical models such as PHREEQC have the ability to simulate the $\mathrm{pH}$-dependent equilibrium sorption but lack the capability of describing the time-dependent sorption and transport processes [25, 37, 41]. Future models should be extended to account for these $\mathrm{pH}$-dependent reaction-transport processes of $\mathrm{Cu}$ in acidified soils.

According to the experimental results and other earlier reports $[4,7,27,30,35,38,46,52,53,59,60]$, a possible mechanism for $\mathrm{pH}$-dependent sorptiontransport of added to $\mathrm{Cu}$ on acidified soils was proposed as follows (Fig. 4): at higher $\mathrm{pH}, \mathrm{CuOH}^{+}$was sorbed to clay mineral basal surface and edge hydroxyl sites, forming surface precipitates or coprecipitates, which resulted in less mobility of $\mathrm{Cu}$; additionally, weaker complexation between $\mathrm{CuOH}^{+}$and phenolic hydroxyl of DOM could further weaken the transport of $\mathrm{Cu}$. On the contrary, at lower $\mathrm{pH}, \mathrm{Cu}^{2+}$ mainly adsorbed to SOM surface and thus diffusion in SOM particles, with higher mobility (especially shorter time

Table 4. The contribution of micropore diffusion to the overall sorption

\begin{tabular}{|c|c|c|c|c|c|c|c|c|c|c|c|c|}
\hline \multirow{3}{*}{ 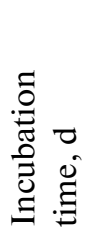 } & \multicolumn{6}{|c|}{$[\mathrm{Cu}]_{0}=31.77 \mathrm{mg} \mathrm{kg}^{-1}$} & \multicolumn{6}{|c|}{$[\mathrm{Cu}]_{0}=317.73 \mathrm{mg} \mathrm{kg}^{-1}$} \\
\hline & \multicolumn{2}{|c|}{ pH 3.19} & \multicolumn{2}{|c|}{ pH 5.10} & \multicolumn{2}{|c|}{ pH 6.92} & \multicolumn{2}{|c|}{ pH 3.19} & \multicolumn{2}{|c|}{ pH 5.10} & \multicolumn{2}{|c|}{ pH 6.92} \\
\hline & $\begin{array}{l}\text { amount, } \\
\mathrm{mg} \mathrm{kg}^{-1}\end{array}$ & $\%$ & $\begin{array}{l}\text { amount, } \\
\mathrm{mg} \mathrm{kg}^{-1}\end{array}$ & $\%$ & $\begin{array}{l}\text { amount, } \\
\mathrm{mg} \mathrm{kg}^{-1}\end{array}$ & $\%$ & $\begin{array}{l}\text { amount, } \\
\mathrm{mg} \mathrm{kg}^{-1}\end{array}$ & $\%$ & $\begin{array}{l}\text { amount, } \\
\mathrm{mg} \mathrm{kg}^{-1}\end{array}$ & $\%$ & $\begin{array}{l}\text { amount, } \\
\mathrm{mg} \mathrm{kg}^{-1}\end{array}$ & $\%$ \\
\hline 5 & 5.24 & 21.07 & 0.36 & 1.20 & 0.13 & 0.42 & 70.40 & 36.71 & 24.49 & 8.26 & 24.56 & 7.86 \\
\hline 10 & 8.09 & 29.19 & 0.81 & 2.57 & 0.30 & 0.97 & 92.39 & 43.22 & 28.61 & 9.51 & 25.83 & 8.23 \\
\hline 28 & 10.18 & 34.14 & 1.13 & 3.57 & 0.48 & 1.53 & 137.21 & 53.06 & 35.78 & 11.62 & 27.99 & 8.86 \\
\hline 90 & 11.74 & 37.42 & 1.23 & 3.86 & 0.80 & 2.50 & 158.09 & 56.56 & 37.20 & 12.03 & 29.72 & 9.35 \\
\hline
\end{tabular}




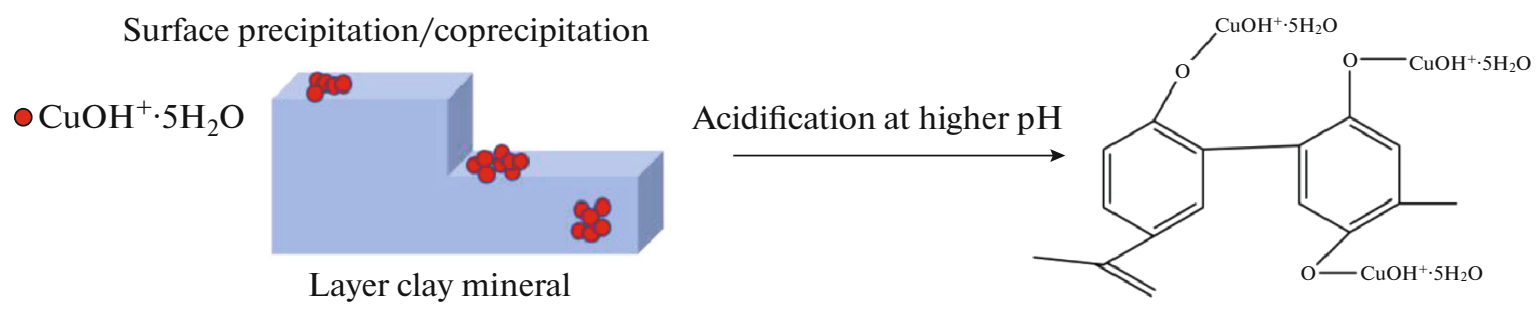

Surface adsorption/occlusion
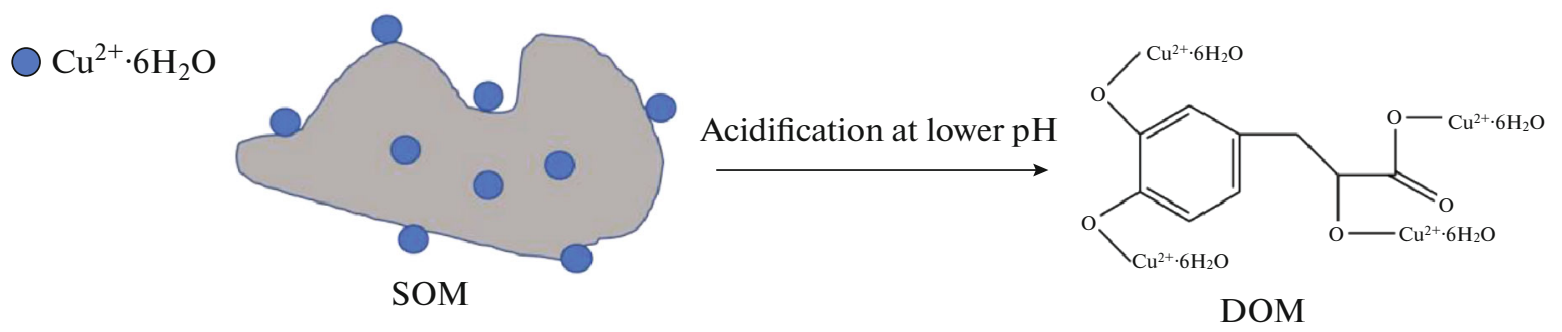

Fig. 4. Possible mechanism for $\mathrm{pH}$-dependent sorption-transport of added $\mathrm{Cu}$.

periods). Which, together with stronger complexation between $\mathrm{Cu}^{2+}$ and carboxyl of DOM, would greatly enhance the transport of $\mathrm{Cu}$.

\section{CONCLUSIONS}

The $\mathrm{pH}$-dependent sorption and transport of $\mathrm{Cu}$ on an acidic brown soil was studied by batch and column experiments. It was shown that $\mathrm{Cu}$ adsorption with $\mathrm{pH}$ yielded two linear segments with different slopes, where at lower $\mathrm{pH}$ Langmuir isotherm fitted better, while at higher $\mathrm{pH}$, Freundlich was better for adsorption. The pseudo-second order kinetic model was better for the description of the slow reaction of $\mathrm{Cu}$ onto Cambisols, with lower $k_{2}$ and $h$ values (1020 times lower) and higher contribution of micropore diffusion (40-60\% higher) at lower $\mathrm{pH}$ than those at higher $\mathrm{pH}$. In addition, the transport of soil $\mathrm{Cu}$ showed significant retardation with $C / C_{0}=0.64$ in BTC curves at higher $\mathrm{pH}$; while it was greatly enhanced under acidification (e.g., $\mathrm{pH}$ 3.17), with full breakthrough $\left(C / C_{0}=1\right)$. In summary, two different mechanisms for $\mathrm{pH}$-dependent sorption-transport of added $\mathrm{Cu}$ on Cambisols were proposed: at lower $\mathrm{pH}$, $\mathrm{Cu}^{2+}$ adsorbed to SOM surface and stronger complexation with DOM, resulting in stronger mobility and transport; while at higher $\mathrm{pH}, \mathrm{CuOH}^{+}$was precipitated on clay mineral surface and weaker complexation with DOM, slowing down the transport of $\mathrm{Cu}$.

\section{ACKNOWLEDGMENTS}

The authors thank the anonymous reviewers and editors for helpful comments and constructive advice on this manuscript.

\section{FUNDING}

This work was financially supported by the National Natural Science Foundation of China (31670471, 41271254) and high-level talent project of Ludong University.

\section{CONFLICT OF INTEREST}

The authors declare that they have no competing financial interests.

\section{REFERENCES}

1. R. A. Alvarez-Puebla, C. Aisa, J. Blasco, J. C. Echeverría, B. Mosquera, and J. J. Garrido, "Copper heterogeneous nucleation on a palygorskitic clay: an XRD, EXAFS and molecular modeling study," Appl. Clay Sci. 25 (1-2), 103-110 (2004). https://doi.org/10.1016/j.clay.2003.09.002

2. M. Arias-Estévez, J. C. Nóvoa-Muñoz, M. Pateiro, and J. E. López-Periago, "Influence of aging on copper fractionation in an acid soil," Soil Sci. 172 (3), 225-232 (2007). https://doi.org/10.1097/SS.0b013e31803063ab

3. M. Baghdadi, "UT (University of Tehran) isotherm as a novel and useful adsorption isotherm for investigation of adsorptive removal of pollutants," J. Environ. Chem. Eng. 5 (2), 1906-1919 (2017).

https://doi.org/10.1016/j.jece.2017.03.037

4. N. Barsova, G. Motuzova, K. Kolchanova, A. Stepanov, M. Karpukhin, and T. Minkina, "The effect of humic substances on $\mathrm{Cu}$ migration in the soil profile," Chem. Ecol. 35 (1), 86-101 (2019). https://doi.org/10.1080/02757540.2018.1540613

5. S. Bevara, P. Giri, S. N. Achary, G. Bhallerao, R. K. Mishra, A. Kumar, C. P. Kaushik, and A. K. Tyagi, "Synthetic $\mathrm{Na} / \mathrm{K}$-birnessite for efficient management of 
Sr (II) from nuclear waste," J. Environ. Chem. Eng. 6 (6), 7200-7213 (2018).

https://doi.org/10.1016/j.jece.2018.11.021

6. G. H. Bolt, M. F. De Boodt, M. H. B. Hayes, and M. B. McBride, Interactions at the Soil Colloid-Soil Solution Interface (Kluwer, Dordrecht, 1991). https://doi.org/10.1007/978-94-017-1909-4

7. S. Boudesocque, E. Guillon, M. Aplincourt, E. Marceau, and L. Stievano, "Sorption of $\mathrm{Cu}(\mathrm{II})$ onto vineyard soils: macroscopic and spectroscopic investigations," J. Colloid Interface Sci. 307 (1), 40-49 (2007). https://doi.org/10.1016/j.jcis.2006.10.080

8. H. B. Bradl, "Adsorption of heavy metal ions on soils and soils constituents," J. Colloid Interface Sci. 277 (1), 1-18 (2004).

https://doi.org/10.1016/j.jcis.2004.04.005

9. G. Brunetto, P. A. A. Ferreira, G. W. Melo, C. A. Ceretta, and M. Toselli, "Heavy metals in vineyards and orchard soils,” Rev. Bras. Fruticult. 39 (2), e-263 (2017). https://doi.org/10.1590/0100-29452017263

10. W. H. Casey and T. W. Swaddle, "Why small? The use of small inorganic clusters to understand mineral surface and dissolution reactions in geochemistry," Rev. Geophys. 41 (2), 1008 (2003). https://doi.org/10.1029/2002RG000118

11. M. Ćendić, R. J. Deeth, A. Meetsma, E. Garribba, D. Sanna, and Z. D. Matović, "Chelating properties of EDTA-type ligands containing six-membered backbone ring toward copper ion: Structure, EPR and TD-DFT evaluation," Polyhedron 124, 215-228 (2017). https://doi.org/10.1016/j.poly.2016.12.025

12. P. K. Chaturvedi, C. S. Seth, and V. Misra, "Sorption kinetics and leachability of heavy metal from the contaminated soil amended with immobilizing agent (humus soil and hydroxyapatite)," Chemosphere 64 (7), 1109-1114 (2006). https://doi.org/10.1016/j.chemosphere.2005.11.077

13. D. Curtin, M. E. Peterson, and C. R. Anderson, "pHdependence of organic matter solubility: base type effects on dissolved organic $\mathrm{C}, \mathrm{N}, \mathrm{P}$, and $\mathrm{S}$ in soils with contrasting mineralogy," Geoderma 271, 161-172 (2016). https://doi.org/10.1016/j.geoderma.2016.02.009

14. H.H. Du, Q. Y. Huang, M. Zhou, B. Q. Tie, M. Lei, X. D. Wei, X. L. Liu, and Y. Yang, "Sorption of Cu (II) by Al hydroxide organo-mineral coprecipitates: microcalorimetry and NanoSIMS observations," Chem. Geol. 499, 165-171 (2018). https://doi.org/10.1016/j.chemgeo.2018.09.026

15. T. A. Elbana and H. M. Selim, "Copper mobility in acidic and alkaline soils: miscible displacement experiments," Soil Sci. Soc. Am. J. 75 (6), 2101-2110 (2011). https://doi.org/10.2136/sssaj2011.0185

16. D. Fangueiro, A. Bermond, E. Santos, H. Carapuça, and A. Duarte, "Kinetic approach to heavy metal mobilization assessment in sediments: choose of kinetic equations and models to achieve maximum information," Talanta 66 (4), 844-857 (2005). https://doi.org/10.1016/j.talanta.2004.12.036

17. D. Fernández-Calviño, J. C. Nóvoa-Muñoz, M.DíazRaviña, and M. Arias-Estévez, "Copper accumulation and fractionation in vineyard soils from temperate humid zone (NW Iberian Peninsula)," Geoderma 153 (1-2), 119-129 (2009).

https://doi.org/10.1016/j.geoderma.2009.07.024

18. K. Flogeac, E. Guillon, and M. Aplincourt, "Surface complexation of copper (II) on soil particles: EPR and XAFS studies,” Environ. Sci. Technol. 38 (11), 30983103 (2004). https://doi.org/10.1021/es049973f

19. K. Y. Foo and B. H. Hameed, "Insights into the modeling of adsorption isotherm systems," Chem. Eng. J. 156 (1), 2-10 (2010). https://doi.org/10.1016/j.cej.2009.09.013

20. C. C. Fu, C. Tu, H. B. Zhang, Y. Li, L. Z. Li, Q. Zhou, K. G. Scheckel, and Y. M. Luo, "Soil accumulation and chemical fractions of $\mathrm{Cu}$ in a large and long-term coastal apple orchard, North China," J. Soils Sediments 20, 3712-3721 (2020).

https://doi.org/10.1007/s11368-020-02676-2

21. M. Graouer-Bacart, S. Sayen, and E. Guillon, "Macroscopic and molecular approaches of enrofloxacin retention in soils in presence of Cu (II)," J. Colloid Interface Sci. 408, 191-199 (2013). https://doi.org/10.1016/j.jcis.2013.07.035

22. Y. S. Ho and G. McKay, "Pseudo-second order model for sorption processes," Process. Biochem. 34 (5), 451465 (1999). https://doi.org/10.1016/S0032-9592(98)00112-5

23. Q. H. Hu, Z. J. Xiao, X. M. Xiong, G. M. Zhou, and X. H. Guan, "Predicting heavy metals' adsorption edges and adsorption isotherms on $\mathrm{MnO}_{2}$ with the parameters determined from Langmuir kinetics," J. Environ. Sci. 27, 207-216 (2015). https://doi.org/10.1016/j.jes.2014.05.036

24. IUSS Working Group WRB, World Reference Base for Soil Resources 2014, Update 2015, International Soil Classification System for Naming Soils and Creating Legends for Soil Maps, World Soil Resources Reports No. 106 (UN Food and Agriculture Organization, Rome, 2015). http://www.fao.org/3/i3794en/I3794en.pdf.

25. S. H. Ji and M. L. Wu, "Study on simulation of heavy metal transport in soil using PHREEQC," Appl. Mechan. Mater. 522-524, 153-160 (2014).

https://doi.org/10.4028/www.scientific.net/amm.522524.153

26. B. Kandsi, K. Benhabib, G. Mimanne, M. Djellouli, and S. Taleb, "Assessment of the potential mobility of copper in contaminated soil samples by column leaching test," Eurasian J. Soil Sci., 8 (1), 27-34 (2019). https://doi.org/10.18393/ejss.485939

27. T. Karlsson, P. Persson, and U. Skyllberg, "Complexation of copper (II) in organic soils and in dissolved organic matter-EXAFS evidence for chelate ring structures," Environ. Sci. Technol. 40 (8), 2623-2628 (2006). https://doi.org/10.1021/es052211f

28. K. G. Karthikeyan, H. A. Elliott, and J. Chorover, "Role of surface precipitation in copper sorption by the hydrous oxides of iron and aluminum," J. Colloid Interface Sci. 209 (1), 72-78 (1999). https://doi.org/10.1006/jcis.1998.5893

29. M. Komárek, E. Čadková, V. Chrastný, F. Bordas, and J. C. Bollinger, "Contamination of vineyard soils with fungicides: a review of environmental and toxicological 
aspects," Environ. Int. 36 (1), 138-151 (2010)

https://doi.org/10.1016/j.envint.2009.10.005

30. T. N. Kropacheva, A. S. Antonova, and V. I. Kornev, "The influence of aminopolycarboxylates on the sorption of copper(II) cations by (hydro)oxides of iron, aluminum, and manganese," Eurasian Soil Sci. 49, 765772 (2016).

https://doi.org/10.1134/S1064229316070061

31. K. Lock and C. R. Janssen, "Influence of aging on metal availability in soils," Rev. Environ. Contam. Toxicol. 178, 1-21 (2003).

https://doi.org/10.1007/0-387-21728-2_1

32. E. D. Lodygin, "Sorption of $\mathrm{Cu}^{2+}$ and $\mathrm{Zn}^{2+}$ ions by humic acids of tundra peat gley soils (histic reductaquic cryosols)," Eurasian Soil Sci. 52, 769-777 (2019). https://doi.org/10.1134/S1064229319070093

33. R. K. Lu, Analysis Methods in Soil Agrochemistry (Chinese Agricultural Science and Technology Press, Beijing, 2000). ISBN 7-80119-925-1

34. Y. B. Ma, E. Lombi, I. W. Oliver, A. L. Nolan, and M. J. McLaughlin, "Long-term aging of copper added to soils," Environ. Sci. Technol. 40 (20), 6310-6317 (2006).

https://doi.org/10.1021/es060306r

35. A. Manceau and A. Matynia, "The nature of $\mathrm{Cu}$ bonding to natural organic matter," Geochim. Cosmochim. Acta 74 (9), 2556-2580 (2010). https://doi.org/10.1016/j.gca.2010.01.027

36. J. Mehlhorn, J. Besold, J. S. L. Pacheco, J. P. Gustafsson, R. Kretzschmar, and B. Planer-Friedrich, "Copper mobilization and immobilization along an organic matter and redox gradient-Insights from a Mofette site," Environ. Sci. Technol. 52 (23), 13698-13707 (2018). https://doi.org/10.1021/acs.est.8b02668

37. K. Michel, M. Roose, and B. Ludwig, "Comparison of different approaches for modelling heavy metal transport in acidic soils," Geoderma 140 (1-2), 207-214 (2007). https://doi.org/10.1016/j.geoderma.2007.04.005

38. T. M. Minkina, D. L. Pinskii, T. V. Bauer, D. G. Nevidomskaya, S. S. Mandzhieva, and S. N. Sushkova, "Sorption of Cu by chernozems in southern Russia," J. Geochem. Expl. 174, 107-112 (2017).

https://doi.org/10.1016/j.gexplo.2016.06.002

39. N. Mirlean, A, Roisenberg, and J. O. Chies, "Metal contamination of vineyard soils in wet subtropics (southern Brazil)," Environ. Pollut. 149 (1), 10-17 (2007). https://doi.org/10.1016/j.envpol.2006.12.024

40. L. A. Oste, E. J. M. Temminghoff, and W. H. van Riemsdijk, "Solid-solution partitioning of organic matter in soils as influenced by an increase in $\mathrm{pH}$ or Ca concentration," Environ. Sci. Technol. 36 (2), 208-214 (2002).

https://doi.org/10.1021/es0100571

41. D. L. Parkhurst and L. Wissmeier, "PhreeqcRM: A reaction module for transport simulators based on the geochemical model PHREEQC," Adv. Water Res. 83, 176-189 (2015).

https://doi.org/10.1016/j.advwatres.2015.06.001

42. D. L. Pinskii, T. M. Minkina, S. S. Mandzhieva, Y. A. Fedorov, T. V. Bauer, and D. G. Nevidomskaya, "Adsorption features of $\mathrm{Cu}$ (II), $\mathrm{Pb}$ (II), and $\mathrm{Zn}$ (II) by an ordinary chernozem from nitrate, chloride, acetate, and sulfate solutions," Eurasian Soil Sci. 47, 10-17 (2014). https://doi.org/10.1134/S1064229313110069

43. W. Plazinski, J. Dziuba, and W. Rudzinski, "Modeling of sorption kinetics: the pseudo-second order equation and the sorbate intraparticle diffusivity," Adsorption 19, 1055-1064 (2013). https://doi.org/10.1007/s10450-013-9529-0

44. Y. B. Qi, J. Zhu, Q. L. Fu, H. Q. Hu, and Q. Y. Huang, "Sorption of $\mathrm{Cu}$ by humic acid from the decomposition of rice straw in the absence and presence of clay minerals,” J. Environ. Manage. 200, 304-311 (2017).

https://doi.org/10.1016/j.jenvman.2017.05.087

45. S. Sayen, J. Mallet, and E. Guillon, "Aging effect on the copper sorption on a vineyard soil: column studies and SEM-EDS analysis,” J. Colloid Interface Sci. 331 (1), 47-54 (2009). https://doi.org/10.1016/j.jcis.2008.11.049

46. M. L. Schlegel and A. Manceau, "Binding mechanism of $\mathrm{Cu}$ (II) at the clay-water interface by powder and polarized EXAFS spectroscopy," Geochim. Cosmochim. Acta 113, 113-124 (2013). https://doi.org/10.1016/j.gca.2013.03.019

47. S. Sen Gupta and K. G. Bhattacharyya, "Kinetics of adsorption of metal ions on inorganic materials: a review," Adv. Colloid Interface Sci. 162 (1-2), 39-58 (2011). https://doi.org/10.1016/j.cis.2010.12.004

48. D. L. Sparks, Soil Physical Chemistry, 2nd ed. (CRC Press, Boca Raton, 1999). ISBN 9780873718837

49. P. Srivastava, B. Singh, and M. Angove, "Competitive adsorption behavior of heavy metals on kaolinite," J. Colloid Interface Sci. 290, 28-38 (2005). https://doi.org/10.1016/j.jcis.2005.04.036

50. Q. Sun, T. T. Li, A. K. Alva, and Y. C. Li, "Mobility and fractionation of copper in sandy soils," Environ. Pollut. Bioavailability 31 (1), 18-23 (2019). https://doi.org/10.1080/09542299.2018.1558114

51. M. A. Tahir, H. N. Bhatti, and M. Iqbal, "Solar Red and Brittle Blue direct dyes adsorption onto Eucalyptus angophoroides bark: equilibrium, kinetics and thermodynamic studies," J. Environ. Chem. Eng. 4 (2), 24312439 (2016). https://doi.org/10.1016/j.jece.2016.04.020

52. E. J. M. Temminghoff, S. E. A. T. M. van der Zee, and F. A. M. de Haan, "Copper mobility in a copper-contaminated sandy soil as affected by $\mathrm{pH}$ and solid and dissolved organic matter," Environ. Sci. Technol. 31 (4), 1109-1115 (1997). https://doi.org/10.1021/es9606236

53. R. M. Tinnacher, M. Holmboe, C. Tournassat, I. C. Bourg, and J. A. Davis, "Ion adsorption and diffusion in smectite: Molecular, pore, and continuum scale views," Geochim. Cosmochim. Acta 177, 130-149 (2016). https://doi.org/10.1016/j.gca.2015.12.010

54. J. Y. Wang, Q. H. Liu, J. L. Li, S. A. Jin, and Y. B. Yuan, "Analysis on the characteristic and cause of orchard soil acidification in the area of Shandong Peninsula," Chin. Agric. Sci. Bull. 26 (16), 164-169 (2010). https://doi.org/CNKI:SUN:ZNTB.0.2010-16-037

55. Q. Y. Wang, J. S. Liu, Y. Wang, and H. W. Yu, “Accumulations of copper in apple orchard soils: distribution 
and availability in soil aggregate fractions," J. Soils Sediments 15 (5), 1075-1082 (2015).

https://doi.org/10.1007/s11368-015-1065-y

56. P. X. Wu, Q. Zhang, Y. P. Dai, N. W. Zhu, Z. Dang, P. Li, J. H. Wu, and X. D. Wang, "Adsorption of Cu (II), $\mathrm{Cd}$ (II) and $\mathrm{Cr}$ (III) ions from aqueous solutions on humic acid modified Ca-montmorillonite," Geoderma 164 (3-4), 215-219 (2011). https://doi.org/10.1016/j.geoderma.2011.06.012

57. L. Zhang, Y. X. Pan, W. Lv, and Z. T. Xiong, "Physiological responses of biomass allocation, root architecture, and invertase activity to copper stress in young seedlings from two populations of Kummerowia stipulacea (Maxim.) Makino," Ecotoxicol. Environ. Saf. 104, 278-284 (2014).

https://doi.org/10.1016/j.ecoenv.2014.03.013

58. L. Y. L. Zhao, R. Schulin, L. P. Weng, and B. Nowack, "Coupled mobilization of dissolved organic matter and metals ( $\mathrm{Cu}$ and $\mathrm{Zn}$ ) in soil columns," Geochim. Cosmochim. Acta 71 (14), 3407-3418 (2007).

https://doi.org/10.1016/j.gca.2007.04.020

59. S. W. Zhou, Y. B. Ma, and M. G. Xu, "Ageing of added copper in bentonite without and with humic acid," Chem. Spec. Bioavailability 21 (3), 175-184 (2009). https://doi.org/10.3184/095422909X12473330533592

60. S. W. Zhou, M. G. Xu, Y. B. Ma, S. B. Chen, and D. P. Wei, "Aging mechanism of copper added to bentonite," Geoderma 147 (1-2), 86-92 (2008).

https://doi.org/10.1016/j.geoderma.2008.08.003

61. X. Z. Zou, C. L. Zhang, L. Wei, J. F. Ning, and S. H. Yang, "Effect of electrolyte concentration on release of hydrogen ions from soils adsorbing copper ions," Acta Pedol. Sin. 48 (5), 964-970 (2011). https://doi.org/CNKI:SUN:TRXB.0.2011-05-009 